\section{OPTIMIZATION AND CHARACTERIZATION OF EXO-POLYGALACTURONASE BY Aspergillus niger CULTURED VIA SOLID STATE FERMENTATION}

Halifah Pagarraa, Roshanida A. Rahmanb*, Nur Izyan Wan Azeleeb $^{b}$, Rosli Md Illias ${ }^{b}$

aDepartment of Biology, Faculty of Mathematics and Natural Sciences, Universitas Negeri Makassar, South Sulawesi, Indonesia

bSchool of Chemical and Energy Engineering, Faculty of Engineering, Universiti Teknologi Malaysia, 81310 UTM Johor Bahru, Johor, Malaysia
Article history

Received

28 November 2017

Received in revised form

9 August 2018

Accepted

1 September 2018

Published online

15 December 2018

*Corresponding author

r-anida@.utm.my

\section{Graphical abstract}
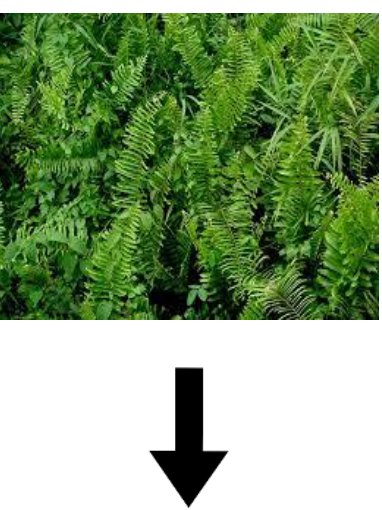<smiles>CCOC(=O)C1=C[C@H](OC(CC)CC)[C@H](NC(C)=O)[C@H](N)C1</smiles>

Exo-polygalacturonase

\begin{abstract}
Polygalacturonases represent an important member of pectinases group of enzymes with immense industrial applications. The activity of exo-polygalacturonase produced by Aspergillus niger was studied in solid state fermentation (SSF) using Nephrolepis biserrata leaves as substrate. Central composite design (CCD) was used to optimize four significant variables resulted from the screening process that has been initially analyzed for the production of exo-polygalacturonase which are incubation time, temperature, concentration of pectin and moisture content. The optimum exo-polygalacturonase production obtained was $54.64 \mathrm{U} / \mathrm{g}$ at 120 hours of incubation time, temperature at $34^{\circ} \mathrm{C}$ $5.0 \mathrm{~g} / \mathrm{L}$ of pectin concentration and $75.26 \%$ of moisture content. For partial characterization of exo-polygalacturonase, the optimum temperature and $\mathrm{pH}$ were obtained at $50^{\circ} \mathrm{C}$ and $\mathrm{pH} 4.0$, respectively. SDS-PAGE analysis showed that molecular weight of exo-polygalacturonase were 35 and $71 \mathrm{kDa}$. This study has revealed a significant production of exo-polygalacturonase by A. niger under SSF using cheap and easily available substrate and thus could found immense potential application in industria sectors and biotechnology.
\end{abstract}

Keywords: Nephrolepis biserrata, Exo-polygalacturonase, Solid-state fermentation Response Surface Methodology and Aspergillus niger

\begin{abstract}
Abstrak
Poligalakturonase merupakan ahli penting dalam kumpulan enzim pektinase dengan aplikasi besar dalam industri. Aktiviti ekso-poligalakturonase yang dihasilkan oleh Aspergillus niger telah dikaji dalam fermentasi keadaan pepejal (FKP) menggunakan daun Nephrolepis biserrata sebagai substrat. Reka bentuk komposit berpusat (RBKB) telah digunakan untuk mengoptimumkan empat pemboleh ubah yang didapati signifikan hasil daripada proses penyaringan awal yang telah dianalisa iaitu masa pengeraman, suhu, kepekatan pektin dan kelembapan medium. Penghasilan ekso-poligalakturonase optimum yang diperoleh adalah $54.64 \mathrm{U} / \mathrm{g}$ pada masa pengeraman 120 jam, suhu pada $34^{\circ} \mathrm{C}, 5.0 \mathrm{~g} / \mathrm{L}$ kepekatan pektin dan $75.62 \%$ kandungan kelembapan medium. Bagi pencirian separa ekso-poligalakturonase, suhu dan $\mathrm{pH}$ optimum masing-masing diperolehi pada $50^{\circ} \mathrm{C}$ dan $\mathrm{pH}$ 4.0. Analisis SDS-PAGE menunjukkan bahawa jisim molekul ekso-poligalakturonase adalah 35 dan 71 kDa. Kajian ini telah membuktikan penghasilan signifikan ekso-poligalakturonase oleh A. niger daripada FKP menggunakan substrat
\end{abstract}


murah dan mudah diperolehi sekali gus boleh menjadi potensi besar untuk aplikasi di sektor industri dan bioteknologi.

Kata kunci: Nephrolepis biserrata, ekso-poligalakturonase, fermentasi keadaan pepejal, Rekabentuk komposit berpusat, Aspergillus niger

(C) 2019 Penerbit UTM Press. All rights reserved

\subsection{INTRODUCTION}

Pectinase (EC 3.2.1.15) are a group of enzymes that decompose the pectin from plant tissue into simple molecules such as galacturonic acids [1]. Pectinase, also known as pectic enzyme or pectinolytic enzyme is naturally produced by plants, filamentous fungi, bacteria and yeast [2]. The pectinases are one of the important upcoming enzymes of the commercial sector specially for fruit juice industry as a prerequisites for obtaining well clarified and stable juices with higher yields [3]. Based on pectinase mode of action, it can be divided into three types, namely 1) Protopectinase, 2) Esterases (pectin methylesterases and pectin acetylesterases), 3) Depolimerases, who broke the bands of $a-(1-4)$ glycosidic bonds between galacturonic residues by hydrolysis (Polygalacturonase) and trans-elimination (Pectate lyase and pectin lyase) [4].

Fungi, yeast and bacterial are commonly express and secrete a variety of enzymes involved in the degradation and recycling of complex biopolymers using solid state fermentation process (SSF) [5] - [8]. Aspergillus sp. is one of the effective bioremediation agents [9]. Aspergillus niger was exploited primarily in the food industry and it is generally regarded as safe. In pectin and pectinase industry, application and preparation fungus has mostly obtained from Aspergillus niger [10].

Methods of fermentation such as solid-state fermentation (SSF) and submerged fermentation (SmF) are important for the production of microbial enzymes [11]. SSF is the most suitable fermentation technique involving fungi and microorganisms that require low moisture content [12]. Generally, pectinases from various microorganisms were characterized and the molecular masses is around 13 to $82 \mathrm{kDa}$ [13].

Most of the previous studies uses pectin source from fruits and agricultural waste to produce pectinase. However, no study up to date has focus on using fern leaves as the substrate. Hence, in this study the production of pectinase from Nephrolepis biserrata leaves is being tested. Nephrolepis biserrata is a wild fern that easily grow under palm trees and along the hillsides in Malaysia and other tropical countries. A study by Essuman et al. (2014) shows that the Nephrolepis biserrata powder contains high carbohydrate content $(43.01 \%, \mathrm{~g} / \mathrm{g})$ which indicate a good source for pectin [14].
The goal of this study is to optimize the production of exo-polygalacturonase by Aspergillus niger in solid state fermentation (SSF) using Nephrolepis biserrata leaves pretreated as the substrate and to partially characterize the enzymes. This study will reveal a significant production of exo-polygalacturonase by $A$. niger under SSF using cheap and easily available substrate and thus could found immense potential application in industrial sectors and biotechnology

\subsection{METHODOLOGY}

\subsection{Sample}

Fresh Nephrolepis biserrata leaves were collected within the vicinity of Universiti Teknologi Malaysia (UTM).

\subsection{Inoculum Preparation}

Fungal culture Aspergillus niger (ATCC 1010) was obtained from Bioprocess Engineering Laboratory, UTM. It was periodically sub-cultured on PotatoDextrose Agar (PDA) medium and maintained at 4 ${ }^{\circ} \mathrm{C}$. Fungus was grown on PDA plates for 5-7 days to obtain sufficient quantity of matured spores. These spores were scrapped out, suspended in $0.1 \% \mathrm{w} / \mathrm{V}$ Tween- 80 and then transferred to sterile test tubes. These suspended spores were used as seed culture spores for inoculum preparation. All chemicals used were of analytical grades from Merck and Fisher Scientific unless otherwise stated.

\subsection{Solid State Fermentation}

Dried, grinded and sifted Nephrolepis biserrata leaves were used as the substrate. The leaves were weighed at $10 \mathrm{~g} /$ flask into a $500 \mathrm{ml}$ Erlenmeyer flask. Nutrients, $\mathrm{MgSO}_{4} .7 \mathrm{H}_{2} \mathrm{O}$ at $0.5 \mathrm{~g} / \mathrm{L}, \mathrm{KH}_{2} \mathrm{PO}_{4}$ at $0.5 \mathrm{~g} / \mathrm{L}$, FeSO ${ }_{4} .7 \mathrm{H}_{2} \mathrm{O}$ at $0.005 \mathrm{~g} / \mathrm{L}$, pectin Nephrolepis biserrata leaves at $10 \mathrm{~g} / \mathrm{L}$, yeast at $1 \mathrm{~g} / \mathrm{L}$ and glucose at $10 \mathrm{~g} / \mathrm{L}$ were added to the flask. Next, $50 \mathrm{mM}$ citrate buffer at $\mathrm{pH} 5.0$ was added so that the moisture content reaches $70 \%$ moisture. The substrate mixture was autoclaved for 1 hour at $121^{\circ} \mathrm{C}$ and cooled to room temperature $\left(27^{\circ} \mathrm{C} \pm 1\right)$ before inoculated with the fungus. Solid medium and steriled substrate were inoculated with $10 \%(\mathrm{v} / \mathrm{v})$ from $1 \times 10^{7}$ spores $/ \mathrm{mL}$. Spore suspension was transferred to the flask containing the solid substrate medium, mixed evenly, 
and incubated in an incubator at temperature and time intervals optimized by the design of experiments. The experiment was conducted in two conical flasks in which each flask was sampled three times. Sampling was performed every 24 hours on the first day to 192 hours of incubation. For each sampling, 1 $g$ was removed and was collected for every 24 hours.

\subsection{Exo-polygalacturonase Activity Assay}

For each sample, $1 \mathrm{~g}$ samples were removed then mixed with $10 \mathrm{~mL}$ of citrate buffer $(\mathrm{pH} 5.0)$. The exopolygalacturonase activity was assayed by measuring the release of reducing sugars by the DNS method [15]. Glucose was used as the standard. In a test tube, $0.5 \mathrm{ml}$ of $1.0 \%(\mathrm{w} / \mathrm{v}$ ) pectin (Sigma) in $0.5 \mathrm{M}$ citrate buffer (pH 5.0) was added to $0.5 \mathrm{ml}$ of diluted enzyme solution. After $15 \mathrm{~min}$ incubation at $50^{\circ} \mathrm{C}$, the reaction was stopped by the addition of $1 \mathrm{ml}$ of DNS and heated in boiling water for $5 \mathrm{~min}$. Next, $5 \mathrm{ml}$ of distilled water was added to each sample. Samples were read at OD $540 \mathrm{~nm}$ in a spectrophotometer. One unit of Exo- polygalacturonase enzymes is defined as the number of $\mu M$ reducing sugars that are measured in terms of glucose, produced because of the action of the enzyme extract $1.0 \mathrm{ml}$ in $1 \mathrm{~min}$ at $35^{\circ} \mathrm{C} \pm 1^{\circ} \mathrm{C}$ [16]. The total soluble protein was determined by Lowry method [17] using BSA (Bovine serum albumin) as standard.

\subsection{Experimental Design and Statistical Analysis}

The experimental design and statistical analysis were made using Design Expert Version 6.0.4 (Stat-Ease, Inc., Minneapolis, MN, USA) software. The RSM used in the present study is a central composite experimental design (CCD) [18] involving four different factors. Experiments were conducted in a randomized fashion. The CCD contains a total of 30 experimental trials involving the replications of the central points. The dependent variables selected for this study were exo-polygalacturonase activity (U/g). The independent variables chosen were incubation time (h), $X_{1}$; temperature $\left({ }^{\circ} \mathrm{C}\right), X_{2}$; pectin ( $\left./ \mathrm{L} / \mathrm{L}\right), \mathrm{X}_{3}$ and moisture content $(\%), X_{4}$. Once the experiments were performed, a second order polynomial equation (1) shown below was used to describe the effect of variables in terms of linear, quadratic and cross product terms. In CCD, the range and levels of the variables investigated in this study are as given in the Table 1.
Table 1 Code and actual values of the factors in central composite design

\begin{tabular}{|c|c|c|c|c|c|c|}
\hline \multirow[b]{2}{*}{ Var } & \multirow[b]{2}{*}{ Parameter } & \multicolumn{5}{|c|}{ Level } \\
\hline & & $-a$ & -1 & 0 & 1 & $+a$ \\
\hline$X_{1}$ & $\begin{array}{c}\text { Incubation } \\
\text { time (h) }\end{array}$ & 14.40 & 24 & 72 & 120 & 129.60 \\
\hline$x_{2}$ & $\begin{array}{c}\text { Temperature } \\
\left({ }^{\circ} \mathrm{C}\right)\end{array}$ & 25.20 & 26 & 30 & 34 & 34.80 \\
\hline$x_{3}$ & $\begin{array}{c}\text { Pectin conc. } \\
(\mathrm{g} / \mathrm{L})\end{array}$ & 4 & 5 & 10 & 15 & 16 \\
\hline$X_{4}$ & $\begin{array}{c}\text { Moisture } \\
\text { content (\%) }\end{array}$ & 74 & 75 & 80 & 85 & 86 \\
\hline
\end{tabular}

Experimental data were analyzed to fit the following regression model with interaction terms are given below:

$$
\begin{aligned}
Y= & b_{0}+b_{1} X_{1}+b_{2} X_{2}+b_{3} X_{3}+b_{4} X_{4}+b_{11} X_{1}^{2}+ \\
& b_{22} X_{2}^{2}+b_{33} X_{3}^{2}+b_{44 X} X_{4}^{2}+X_{1} X_{2}+X_{1} X_{3}+ \\
& X_{1} X_{4}+X_{2} X_{3}+X_{2} X_{4}+X_{3} X_{4}
\end{aligned}
$$

Where, $Y$ represents exo-polygalacturonase activity $(\mathrm{U} / \mathrm{g})$, while the $X_{1}, X_{2}, X_{3}$ and $X_{4}$ represent temperature, time of incubation, concentration of pectin, and moisture content of the substrate, respectively. The regression model was generated by the Design Expert software after considering all the variables. The model has one designation offset, 4 linear terms, quadratic terms 4, and 6 interactions.

\subsection{Characterization of Crude of Exo- polygalacturonase}

\subsubsection{Effect of $\mathrm{pH}$ on Exo-polygalacturonase Activity and Stability}

The effect of $\mathrm{pH}$ on exo-polygalacturonase activity was determined by incubating the reaction mixture at $\mathrm{pH}$ values ranging from 4.0 to 6.0 , under standard enzyme assay conditions. The $\mathrm{pH}$ stability of the enzyme was evaluated by measuring the residual activity, under standard enzyme assay conditions, after incubating the enzyme for $24 \mathrm{~h}$ at $4^{\circ} \mathrm{C}$ at various $\mathrm{pH}$ from 2.5 to 7.5. The buffers employed in these measurements were citrate/phosphate buffer $(\mathrm{pH} 3.0$ and 6.0 -9.0). All the experiments were conducted in triplicates and the results show the mean values of the activities. 


\subsubsection{Effect of Temperature on Exo-polygalacturonase Stability}

The thermostability of the enzyme was determined by measuring the residual activity, under standard enzyme assay conditions, after incubating the enzyme solution for $60 \mathrm{~min}$ at various temperatures from $50^{\circ} \mathrm{C}$ to $70^{\circ} \mathrm{C}$, at $\mathrm{pH}$ optimum. All the experiments were conducted in triplicates and the results show the mean values of the activities.

\subsection{SDS-Page Analysis}

Determination of molecular weight of exopolygalacturonase was performed by using Sodium Dodecyl Sulphate Polyacrylamide Gel Electrophoresis (SDS-PAGE) [19]. This method is an important way to carry out protein analysis and characterization. Each protein differs from one another by the amino acid sequence. The amino acid sequences give each protein a unique charge, size and shape. A total of $12 \%(\mathrm{v} / \mathrm{v})$ gel separator and $5 \%(\mathrm{v} / \mathrm{v})$ gel compiler is provided in the set of gel plates. Samples of $20 \mu \mathrm{L}$ were mixed and $5 \mu \mathrm{L}$ of sample buffer as ballast $(20$ $\mu \mathrm{L}+5 \mu \mathrm{L})$ in the Eppendorf tube. The sample was heated at $100^{\circ} \mathrm{C}$ for 5 minutes and placed on ice. The protein solution was thrown for 1 second in a sprayer at 4,000 rpm. The sample $(20 \mu \mathrm{L})$ was loaded into the container. For reference, $10 \mu \mathrm{L}$ molecular weight marker (Protein Marker) was loaded into separate containers. The electrophoresis was carried out at $90 \mathrm{~V}$ for 60 minutes. After the process completed, the gel is colored with Coomassie blue. The gel was then dried. The partial characterization of raw exo-polygalacturonase by Aspergillus niger is shown in Figure 7.

\subsection{RESULTS AND DISCUSSION}

\subsection{Optimization of Exo-polygalacturonase}

The probability value (P-value) for each parameter was shown in Table 2. The P-value of less than 0.05 defines the factors as significant. The model is significant with probability of $<0.0001$. The regression coefficient, $R^{2}$ value of 0.9748 indicates the model fit with the experimental data. The optimum level for each variable factor was determined by constructing three-dimensional surface plot based on the mathematical model equation that have been issued. The production of exo-polygalacturonase was achieved at $54.64 \mathrm{U} / \mathrm{g}$. This plot also represents the interaction between two variables while maintaining the third variable (Figure 1 to 2 ).
Table 2 Regression analysis (ANOVA) for the Exopolygalacturonase activity using 2 - level factorial design

\begin{tabular}{|c|c|c|c|c|c|c|}
\hline Source & $\begin{array}{l}\text { Sum of } \\
\text { Squares }\end{array}$ & $\begin{array}{c}\text { Degree } \\
\text { of } \\
\text { Freedom }\end{array}$ & $\begin{array}{l}\text { Mean } \\
\text { Square }\end{array}$ & $\begin{array}{c}\mathrm{F}- \\
\text { value }\end{array}$ & $p$-value & $R$ \\
\hline Model & 2821.69 & 14 & 201.55 & $41.46^{a}$ & $<0.0001^{b}$ & 0.9748 \\
\hline$x_{1}$ & 2069.02 & 1 & 2069.02 & 425.64 & $<0.0001$ & \\
\hline$x_{2}$ & 0.87 & 1 & 0.87 & 0.18 & 0.6780 & \\
\hline$x_{3}$ & 56.27 & 1 & 56.27 & 11.58 & 0.0039 & \\
\hline$X_{4}$ & 160.88 & 1 & 160.88 & 33.10 & $<0.0001$ & \\
\hline$x_{1}{ }^{2}$ & 25.62 & 1 & 25.62 & 5.27 & 0.0065 & \\
\hline $\mathrm{X}_{2}{ }^{2}$ & 55.36 & 1 & 55.36 & 11.39 & 0.0042 & \\
\hline$X_{3}{ }^{2}$ & 16.06 & 1 & 16.06 & 3.30 & 0.0891 & \\
\hline$X_{4}{ }^{2}$ & 4.10 & 1 & 4.10 & 0.84 & 0.3729 & \\
\hline$x_{1} x_{2}$ & 258.21 & 1 & 258.21 & 53.12 & $<0.0001$ & \\
\hline$X_{1} X_{3}$ & 26.68 & 1 & 26.68 & 5.49 & 0.0333 & \\
\hline$X_{1} X_{4}$ & 130.66 & 1 & 130.66 & 26.88 & 0,0001 & \\
\hline$X_{2} X_{3}$ & 11.58 & 1 & 11.58 & 2.38 & 0.1435 & \\
\hline$\times 2 \times 4$ & 11.04 & 1 & 11.04 & 2.27 & 0.1526 & \\
\hline$X_{3} X_{4}$ & 0.42 & 1 & 0.42 & 0.086 & 0.7737 & \\
\hline Residual & 72.91 & 15 & 4.86 & - & - & - \\
\hline $\begin{array}{l}\text { Lack of } \\
\text { Fit }\end{array}$ & 55.47 & 10 & 5.55 & 1.59 & $0.3175^{c}$ & - \\
\hline $\begin{array}{l}\text { Pure } \\
\text { error }\end{array}$ & 17.44 & 5 & 3.49 & - & - & - \\
\hline $\begin{array}{c}\text { Co } \\
\text { Total }\end{array}$ & 2894.60 & 29 & - & - & - & - \\
\hline
\end{tabular}

a F-Value is significant.

bModel is significant, with $\mathrm{p}>\mathrm{F}$ lower than 0.05 .

c model is fit due to insignificant $F$-value.

Standard deviation is 20.2

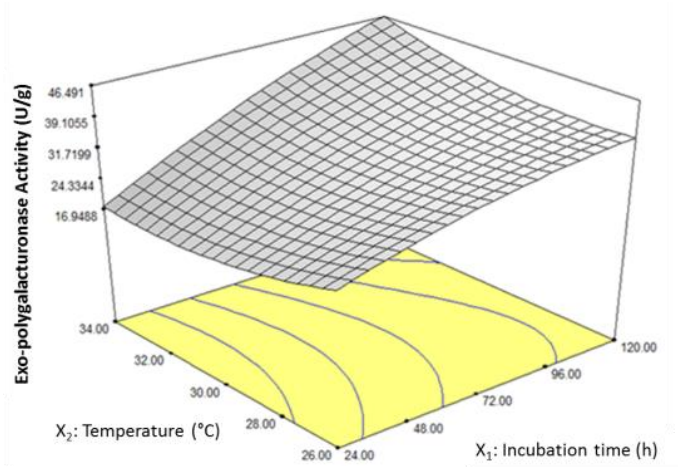

Figure 1 Response Surface plot of exo-polygalacturonase activity: a) effect of incubation time and temperature

Figure 1 shows the effect of incubation time and temperature with the moisture content being radiated at the midpoint value (50\%). Exopolygalacturonase activity increased in tandem with incubation time from 24 hours to 120 hours and temperatures ranging from $26-34^{\circ} \mathrm{C}$. Exopolygalacturonase production is plotted as a function of incubation time and temperature (Figure 1) and the variable shows a significant production of exo-polygalacturonase (ANOVA Table 2). In this study, the optimum incubation time obtained was 120 hours. The screening of incubation time is important for optimizing the enzyme production 
process. If less incubation time is used, it may cause low enzyme synthesis and subsequently low enzyme activity due to insufficient amount of enzyme produced. However, overtime incubation will increase the risk of contamination [20] - [22]. Pectinase production can be obtained starting from the incubation period of 2 days to 9 days [23]. Previously, the optimal pectinase production was obtained at different incubation time of 96 hours [24], 48 hours $[25,26]$ and 120 hours [27].

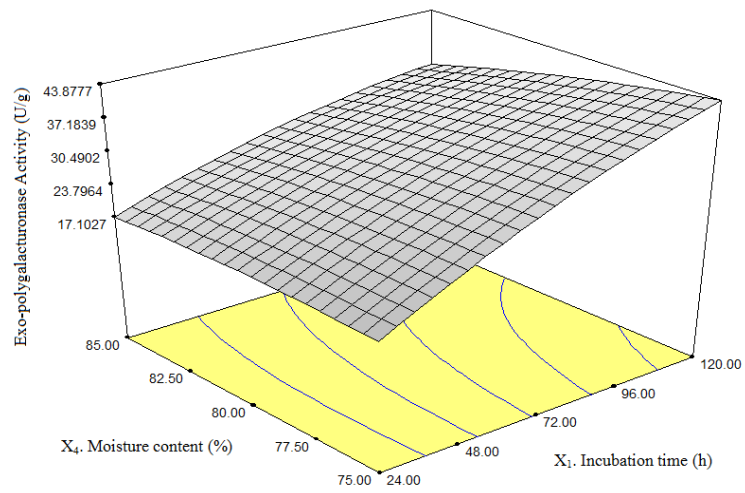

Figure 2 Response Surface plot of exo-polygalacturonase activity: (b) effect of incubation time and moisture content

Furthermore, the effect of incubation time and moisture content of the substrate with temperature which is radiated at midpoint value $(50 \%)$ is shown in Figure 2. Exo-polygalacturonase production is plotted as a function of incubation time and moisture content to show the relationship between both variables. The effect of interaction between incubation time and moisture content was significant with temperature $\left(30^{\circ} \mathrm{C}\right)$ and pectin concentration $(10 \mathrm{~g} / \mathrm{L})$ was observed at the midpoint. In this study, the optimum moisture content was obtained at $75.26 \%$.

Ahmed and Mostafa (2013) state that moisture content is one of the most important parameters in the SSF process [28]. This is because a very high or very low substrate humidity can reduce the production of exo-polygalacturonase due to the disruption of the growth of microorganisms used. The microorganisms require a certain amount of moisture in order to grow well. Therefore, the production of exo-polygalacturonase will be low when the moisture content decreases or exceeds the optimal optimum level [29]. El-Shishtawy et al. (2014) also reported that at high moisture content, the substrate prevents penetration of oxygen and facilitates pollution, while low levels of humidity can inhibit enzyme activity as well as access to nutrients [30]. Generally, the $70 \%$ moisture content of the substrate responded well to all substrates that uses Aspergillus niger and subsequently produce optimum enzyme activity.
3.2 Optimum Temperature and Temperature Stability for Exo-polygalacturonase Activity

Temperature is identified as a critical factor that affects the enzyme and substrate responses. Each enzyme has its optimum temperature to be able to react effectively. The influence of temperature on the activity and stability of exo-polygalacturonase is shown in Figure 3 and Figure 4. In this study, the optimum temperature of exo-polygalacturonase was obtained at $50^{\circ} \mathrm{C}$ as shown in Figure 3. The increased plot in Figure 3 is known as the activation of temperature. At $60^{\circ} \mathrm{C}$, the exo-polygalacturonase activity has begun to decline from $100 \%$ relative activity at $50^{\circ} \mathrm{C}$ to $97.9 \%$ due to enzyme inactivation. Each enzymes has its own optimum temperature range. Temperature exceeding this optimum range will cause the protein to denature and hence losses its activity and becomes inactive.

The optimum temperature of $50^{\circ} \mathrm{C}$ obtained for exo-polygalacturonase activity in this study is similar to the exo-polygalacturonase activity resulting from Aspergillus niger by Mrudula and Anithraraj (2011) and Aspergillus fumigatus by Phutela et al. (2005), $[24,31]$. Other report also states that the optimum temperature on exo-polygalacturonase activity by Aspergillus niger is at temperature ranging from $40^{\circ} \mathrm{C}$ to $60^{\circ} \mathrm{C}$ [32]. The optimum temperature of polygalacturonase enzyme activity was achieved at $40^{\circ} \mathrm{C}$ by Aspergillus sojae [33]. In contrast, another study showed that the optimum temperature for polygalacturonase production was at $55^{\circ} \mathrm{C}$ by Aspergillus sojae fungi [34] and Aspergillus niger [35, 36]. In addition, Mrudula and Anithraraj (2011) report that the optimum temperature for exopolygalacturonase activity of Aspergillus niger is at $60^{\circ} \mathrm{C}$ [24]. Therefore, from these discussions and comparisons it is clear that the optimum temperature for exo-polygalacturonase activity of the genus Aspergillus is within the range of $40^{\circ} \mathrm{C}$ to $50^{\circ} \mathrm{C}$

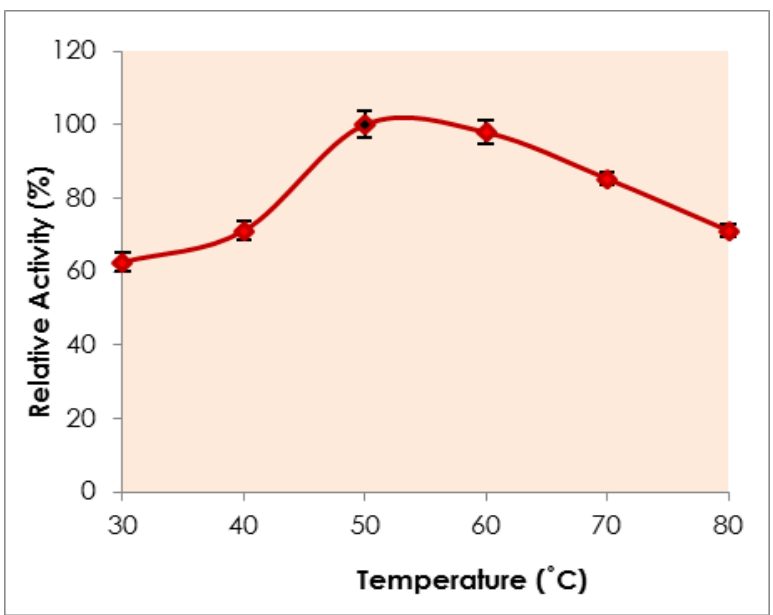

Figure 3 Relative activity of exo-polygalacturonase by Aspergillus niger at different temperatures 


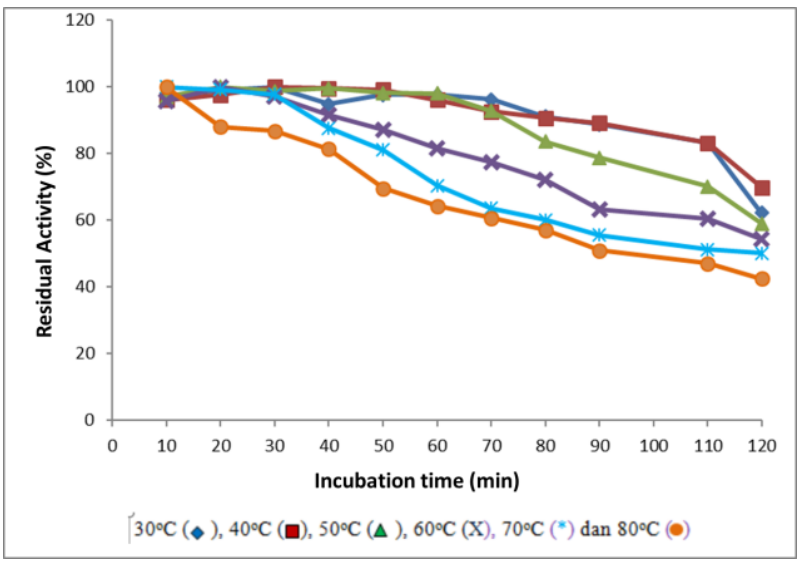

Figure 4 Temperature stability studies on raw exopolygalacturonase by Aspergillus niger at different temperature

Temperature stability studies on raw exopolygalacturonase by Aspergillus niger are shown in Figure 4. From the diagram, exo-polygalacturonase activity was stable at incubation time up to $60 \mathrm{~min}$ at temperatures of $40^{\circ} \mathrm{C}$ and $50^{\circ} \mathrm{C}$ before the relative activity decline below $95 \%$. For temperatures of $30^{\circ} \mathrm{C}$, $60^{\circ} \mathrm{C}$ and $70^{\circ} \mathrm{C}$, exo-polygalacturonase activity was stable until the incubation time reached $30 \mathrm{~min}$ before subsequently reduced drastically. Whereas for temperature $80^{\circ} \mathrm{C}$, a decrease of $13 \%$ residual activity occurred during the first incubation of 10 to $20 \mathrm{~min}$. After 120 minutes, exo-polygalacturonase activity was reduced from $100 \%$ to $62.21 \%\left(30^{\circ} \mathrm{C}\right)$, $69.79 \%\left(40^{\circ} \mathrm{C}\right), 59.04 \%\left(50^{\circ} \mathrm{C}\right), 54.34 \%\left(60^{\circ} \mathrm{C}\right), 50.08 \%$ $70^{\circ} \mathrm{C}$ ) and $42.45 \%\left(80^{\circ} \mathrm{C}\right)$. This result shows that the increase in temperature from 30 to $80^{\circ} \mathrm{C}$ in the range of 10 to 120 min has reduced the stability of enzymes, in which the hydrogen bond interactions do not work properly and caused protein refraction [37]. Exposure of enzymes to high temperatures has led to the abatement of the proteins function. This also strongly depends on the duration of enzymes exposed to the high temperatures. However, in this study, the studied exo-polygalacturonase has proved to be stable at long incubation time (120 $\mathrm{min}$ ) where it still exhibiting exo-polygalacturonase activity at relative activity of $50 \%$ or higher. The enzymes require longer reaction times and high temperatures to bond more strongly with the substrate on the active site [38]. Thermostable temperatures can be divided into 3 groups, i.e. medium thermostable $\left(45-65^{\circ} \mathrm{C}\right)$, thermostable $\left(65-85^{\circ} \mathrm{C}\right)$ and highly thermostable (> $85^{\circ} \mathrm{C}$ ) [38]. This exo-polygalacturonase by Aspergillus niger has managed to maintain its lowest residual activity of $59 \%$ at temperature of $50^{\circ} \mathrm{C}$ and thus making this enzyme in the thermostable group of enzymes.

\section{3 $\mathrm{pH}$ Optimum and $\mathrm{pH}$ Stability of Exo- polygalacturonase Activity}

The effect of $\mathrm{pH}$ on exo-polygalacturonase crude activity by Aspergillus niger was studied at pH 3.0 to $\mathrm{pH} 10.0$ as shown in Figure 5. From this study, the optimum $\mathrm{pH}$ for exo-polygalacturonase is obtained at $\mathrm{pH}$ 4.0. The $\mathrm{pH}$ value obtained in this study is equivalent to the results obtained by Rashmi et al., (2008) who also reported the exo-polygalacturonase by Aspergillus niger showed optimum pH at 4.0 [39]. In this study, the exo-polygalacturonase activity obtained $100 \%$ relative activity at $\mathrm{pH} 4.0$ and started to decrease at pH 5.0 up to $\mathrm{pH}$ 10.0. Based on Figure 5 , the relative activity of exo-polygalacturonase investigated was $76.34 \%$ at $\mathrm{pH} 3$ and increased $100 \%$ of its relative activity at $\mathrm{pH}$ 4.0. Relatively exopolygalacturonase activity decreased at $\mathrm{pH} 5.0$ (90\%), pH 6 (73.9\%), pH 7 (69.2\%), pH 8 (56.9\%), pH 9 (52.4\%) and $\mathrm{pH} 10.0$ (46.8\%) after 120 minutes incubation at $50^{\circ} \mathrm{C}$. This is because $\mathrm{pH}$ changes can affect ionization of active sites of amino acids and caused them to be affected and the occurrence of enzyme disassembly [40].

The study was consistent with other reports showing that the optimum $\mathrm{pH}$ of exopolygalacturonase activity by Fusarium oxysporum, Aspergillus niger and Mucor circinelloides was in the range of 4.0 to $5.0[41,42]$.

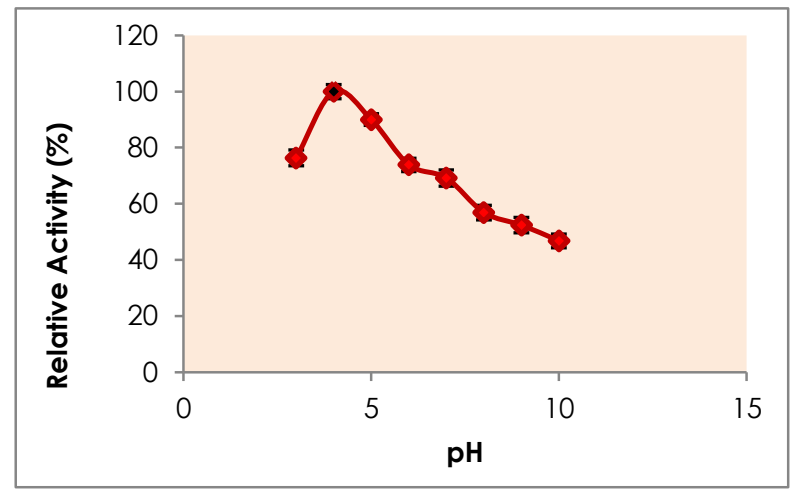

Figure 5 Relative activity of exo-polygalacturonase by Aspergillus niger at different $\mathrm{pH}$ with optimum temperature of $50^{\circ} \mathrm{C}$

Other studies reported that the optimum $\mathrm{pH}$ of exo-polygalacturonase activity from Kluyveromyces wickerhamii [43] and by Trichoderma reesei [44] was at $\mathrm{pH}$ 5.0. The exo-polygalacturonase enzyme produced in the present study with the optimum $\mathrm{pH}$ range is believed to have potential applications in the fruit juices and wine manufacturing industries [36]. 


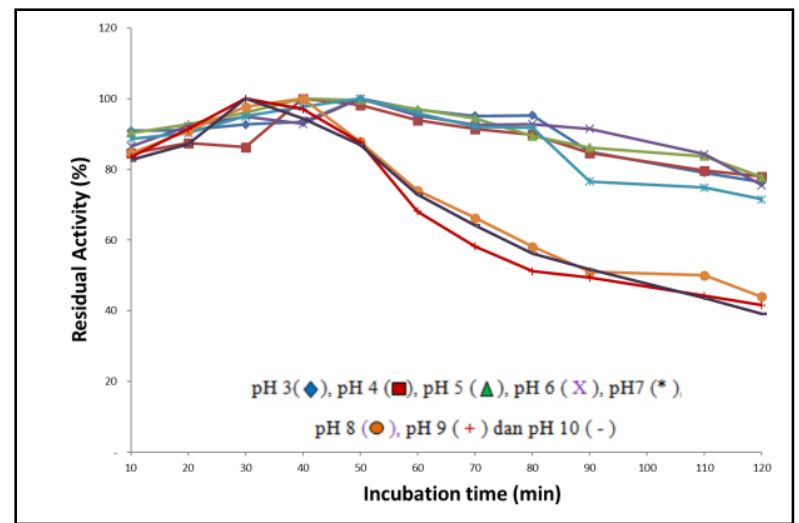

Figure $6 \mathrm{pH}$ stability of exo-polygalacturonase from Aspergillus niger at different $\mathrm{pH}$ (3-10)

The $\mathrm{pH}$ stability of exo-polygalacturonase activity by Aspergillus niger at an optimum temperature of $50^{\circ} \mathrm{C}$ at different $\mathrm{pH}$ within the range of $\mathrm{pH} 3.0$ to $\mathrm{pH}$ 10.0 during 120 minutes of incubation is shown in Figure 6. At $\mathrm{pH}$ range of 3.0 to 7.0 indicates that the activity of exo-polygalacturonase maintained stable above $70 \%$ until after 120 minutes of incubation time. At incubation time of 70 minutes, the stability of exopolygalacturonase activity at $\mathrm{pH}$ range 8.0 to 10.0 decreased by less than $70 \%$, respectively. From this observation, exo-polygalacturonase by Aspergillus niger produced in the present study was stable within the range of $\mathrm{pH} 3$ to $\mathrm{pH} 7$. Whereas for alkaline $\mathrm{pH}$ (8.0 to 10.0), the exo-polygalacturonase activity decreased after incubation time of 40 min until it reached $40 \%$ of residual activity after $120 \mathrm{~min}$ incubation time.

\section{4 Characterization of Exo-polygalacturonase}

\subsubsection{Molecular Weight Determination of Exo- polygalacturonase}

In this study, two protein bands with molecular weight 35 and $71 \mathrm{kDa}$ is observed from the SDS-PAGE analysis (Figure 7). These proteins are labeled as exopolygalacturonase from Aspergillus niger. Buga et al., (2010) reported that the polygalacturonase enzyme from Aspergillus niger isolated in the SDS-PAGE gel showed the existence of endo-exopolygalacturonase at $35 \mathrm{kDa}$ and exopolygalacturonase at $40 \mathrm{kDa}$ [45]. It was also found that polygalacturonase enzyme molecules from Penicillium sp. is at $35 \mathrm{kDa}$ [46], $31 \mathrm{kDa}$ by Rhyzopus oryzae [47] and $31 \mathrm{kDa}$ by Penicillium chrysogenum [48]. Arijit et al., (2013) found that the pectinase from Aspergilus giganteus was $71 \mathrm{kDa}[49,50]$. Other study has also reported that the molecular weight of the exo-polygalacturonase enzyme by Klebsiella $s p$. is at $72 \mathrm{kDa}[51]$.

Meanwhile, different molecular weights of the exo-polygalacturonase enzyme (two strips) were observed from Bacillus sp which was 36 and $72 \mathrm{kDa}$
[52], 36 and $38 \mathrm{kDa}$ by Aspgillus niger [53], 38 and 61 $\mathrm{kDa}$ by Aspergillus niger [54], and 38 and $65 \mathrm{kDa}$ by Aspergillus japonicus [55], respectively. Gummadi et al., (2007) have reported that the molecular weight of exo-polygalacturonase enzymes from various sources such as citrus fruits, apples and plums differ from 25 to $350 \mathrm{kDa}[56]$.

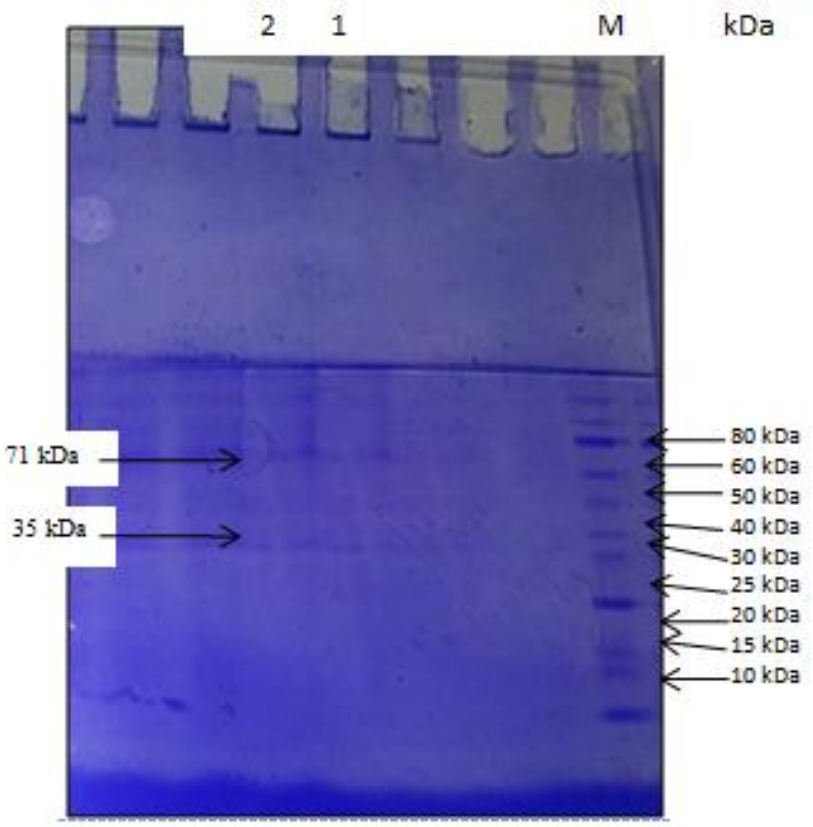

Figure 7 SDS-PAGE analysis of crude exo-polygalacturonase by Aspergillus niger. (lane 1, 2: crude of exopolygalacturonase, $\mathrm{M}$ : marker)

\subsection{CONCLUSION}

Based on the screening process that has been analyzed for the production of exopolygalacturonase, the optimal conditions was achieved at incubation time $120 \mathrm{~h}$, temperature $34^{\circ} \mathrm{C}$, pectin concentration $5.01 \mathrm{~g} / \mathrm{L}$ and moisture content $75.62 \%$. From the optimization process by the CCD, the production of exo-polygalacturonase activity by Aspergillus niger was achieved at 54.64 $\mathrm{U} / \mathrm{g}$ using Nephrolepis biserrata leaves. The crude exo-polygalacturonase by Aspergillus niger was partially characterized. The optimum temperature and $\mathrm{pH}$ were $50^{\circ} \mathrm{C}$ and 4.0 , respectivley. Based on protein visualization by the SDS-PAGE, the molecular weights of the crude exo-polygalacturonase were identified at $35 \mathrm{kDa}$ and $71 \mathrm{kDa}$.

\section{Acknowledgement}

This research is partially supported by UTM HIR Grant: Q.J130000.2446.04G22. The authors are grateful and would like to thank the Bioprocess Engineering laboratory, Faculty of Engineering, Universiti Teknologi Malaysia (UTM) and the Biology Department, Faculty 
of Science and Natural Universitas Negeri Makassar, South Sulawesi, Indonesia for the facilities provided and those who directly or indirectly supported this research.

\section{References}

[1] Pedrolli, D. B., Monteiro A. C., Gomes E. And Carmonal E. C. 2009. Pectin and Pectinases: Production, Characterization and Industrial Application of Microbial Pectinolytic Enzymes. The Open Biotechnology Journal. 3: 9-18. DOI: 10.2174/1874070700903010009.

[2] Maciel, M., Ottoni, C., Santos, C., Lima, N., Moreira, K. and Souza-Motta C. 2013. Production of Polygalacturonases by Aspergillus Section Nigri Strains in Fixed Bed Reactor. Molecules. 18: 1660-1671. DOI: 10.3390/molecules 18021660 .

[3] Tapre and Jain. 2014. Pectinases: Enzymes for Fruit Processing Industry. International Food Research Journal. 21 (2): 447-453. DOI: 20143367106.

[4] Sieiro, C., Garcia, B. F., Lopez, J. S., Da Silva, A. F. And Villa T. G. 2012. Microbial Pectic Enzymes in the Food and Wine Industry. Food Industrial Processes-Methods and Equipment. Dr. Benjamin Valdez (Ed.). 201-218. DOl: $10.5772 / 33403$.

[5] Mamma, D., Kourtoglou, E. And Christokopoulos, P. 2007. Fungal Multienzyme Production on Industrial By-Products of the Citrus-Processing Industry. Bioresource Technology. 99: 2373-2383. DOI: 10.1016/j.biortech.2007.05.018.

[6] Ghosh and Jai, S. 2016. Solid State Fermentation and Food Processing: A Short Review. Journal of Nutrition \& Food Sciences. 6(1): 1-7. DOI: 10.4172/2155-9600.1000453.

[7] Kumar, M. D. J., Saranya, G. M., Suresh, K., Priyadharshini, A. D., Rajakumar and Kalaichelvan, P. T. 2012. Production and Optimization of Pectinase from Bacillus sp. MFW7 using Cassava Waste. Asian Journal of Plant Science and Research. 2(3): 369-375.

[8] Basha, N. S., Rekha, R., Komala, M. and Ruby, S. 2009. Production of Extracellular Anti-leukaemic Enzyme Lasparaginase from Marine Actinomycetes by Solid State and Submerged Fermentation: Purification and Characterisation. Tropical Journal of Pharmaceutical Research. 8(4): 353-360 http://dx.doi.org/10.4314/tjpr.v8i4.45230.

[9] Verma, N., Bansal, M. C. And Kumar, V. 2011. Scanning Electron Microscopic Analysis of Aspergillus niger Pellets and Biofilms under Various Process Conditions. International Journal of Microbiological Research. 2(1): 0811.

[10] Rashmi, R., Murthy, S. K., Sneba, S., Syama, A. and Radhika, V. S. 2008. Partial Purification and Biochemical Characterization of Extracellular Pectinase from Aspergillus niger Isolated from Groundnut Seeds. Journal of Applied Biosciences. 9(1): 378-384. DOI: 20093254516.

[11] Okafor, U. A., Okochi, V. I., Nwodo, S. C., Ebuehi, T. and Onygeme, B. M. O. 2010. Pectinolytic Activity of Wild-Type Filamentous Fungi Fermented on Agro-wastes. African Journal of Microbiology Research. 4(24): 2729-2734. http://www.academicjournals.org/ajmr.

[12] Subramaniyam, R. and Vimala, R. 2012. Solid State and Submerged Fermentation for the Production of Bioactive Substances: A Comparative Study. I.J.S.N. 3(3): 480-486.

[13] Gomes, E., Simoes, R. R. L., da Silva. R, and Silva, D. 2009. Purification of an Exopolygalacturonase from Penicillium viridicatum RFC3 Produced in Submerged Fermentation. International Journal of Microbiology. 1-8. http://dx.doi.org/10.1155/2009/631942.

[14] Essuman, E. K., Ankar-Brewoo, G. M., Barimah, J. and Ofosu, I. W. 2014. Functional Properties of Protein Isolate from Fern Fronds. International Food Research Journal. 21 (5): 2085-2090.
[15] Miller., G. L. 1959. Use of Dinitrosalycylic Acid Reagent for Determination of Reducing Sugar. Anal. Chemical. 1: 426428. DOI: 10.1021/ac60147a030.

[16] Ali, J., Ahmed, J. S., Assad, Q., Hussain, A., Abid, H., and Gul, F. 2010. Optimization of Pectinase Enzyme Production using Sour Oranges Peel (Citrus aurantium L) as Substrate. Pak. J. Biochem. Mol. Biol. 43(3): 126-130.

[17] Lowry, O. H., Rosebrough, N. J., Farr, A. L. and Randall, R. J. 1951. Protein Measurement with Folin Phenol Reagent. J. Biol. Chem. 193: 265-275.

[18] Montgomery, D. C. 2001. Design and Analysis of Experiments. $5^{\text {th }}$ Edition, John Wiley and Sons, Inc. New York.

[19] Laemmli, U. K. 1970. Cleavage of Structural Proteins during the Assembly of the Head of Bacteriophage T4. Nature. 227: 680-685. DOI: 10.1038/227680a0.

[20] Blandino, A., Iqbalsyah, T., Pandiella, S.S., Cantero, D. and Webb, C. 2002. Polygalacturonase Production by Aspergillus awamori on Wheat in Solid-State Fermentation. Appl Microbiol Biotechnol, 58: 164-169. https://doi.org/10.1007/s00253-001-0893-4.

[21] Ramachandran, S., Roopesh, K., Nampoothiri, K. M., Szakacs, G. and. Pandey, A. 2005. Mixed Substrate Fermentation for the Production of Phytase by Rhyzopus spp. using Oilcakes as Substrates. Proress Biorllem. 40(5): 1749-1754. https://doi.org/10.1016/j.procbio.2004.06.040.

[22] Pal, A. and Khanum, F. 2010. Production and Extraction Optimization of Xylanase from Aspergillus niger DFR-5 through Solid-state Fermentation. Bioresource Technol. 101: 7563-7569. DOI: 10.1016/j.biortech.2010.04.033.

[23] Akhter, N., Morshed, M. A., Uddin, A., Begum, F., Sultan, T. and Azad, K. A. 2011. Production of Pectinase by Aspergillus niger Cultured in Solid-state Media. International Journal of Boiscience. 1 (1): 33-42.

[24] Mrudula, S. and Anithraraj, R. 2011. Pectinase Production in Solid-State Fermentation by Aspergillus niger Using Orange Peel as Substrate. Global Journal of Biotechnology and Biochemistry. 6(2): 64-71.

[25] Durairajan, B and Siva Sankari, P. 2014. Optimization of Solid State Fermentation Conditions for the Production of Pectinases by Aspergillus niger. J. Pharm. BioSci. 2: 50-57.

[26] Azzas, H. H., Murad, H. A., Kholif, A. M., Morsy, T. A. Mansour, A. M. and El-Sayed, H. H. 2013. Pectinase Production Optimization and Its Application in Banana Fiber Degradationan. Egyption Journal Nutrtion and Feed. 16(2): 117-125.

[27] Johnson, A. A., Ayodele, S. O., Olanbiwonninu, A. and Christiana, M. O. 2012. Production of Cellulase and Pectinase from Orange Peels by Fungi. Nature and Science. 10(5): 107-112.

[28] Ahmed, S. A. and Mostafa, F. A. 2013. Utilization of Orange Bagasse and Molokhia Stalk for Production of Pectinase Enzyme. Brazilian Journal of Chemical Engineering. 30(3): 449-456.

http://dx.doi.org/10.1590/S0104 66322013000300003

[29] Heerd, Doreen, Yegin, Sirma, Tari, Canan and Marcelo Fernandez-Lahore. 2012. Pectinase Enzyme-complex Production by Aspergillus spp. in Solid-state Fermentation: A Comparative Study. Food and Bioproducts Processing. 90(2): 102-1 10. https://doi.org/10.1016/j.fbp.201 1.08.003.

[30] El-Shishtawy, R. M., Mohamed, S. A., Asiri, A. M., Gomaa, A. M., Ibrahim, I. H. and Al-Talhi, H. A. 2014. Solid Fermentation of Wheat Bran for Hydrolytic Enzymes Production and Saccharification Content by a Local Isolate Bacillus megatherium. BMC Biotechnology. 14(29): 1-8. https://doi.org/10.1186/1472-6750-14-29.

[31] Phutela, U., Vikram Dhuna, V., Shobhna Sandhu, S. and B. S. Chadha, B. S. 2005. Pectinase and Polygalacturonase Production by a Thermophilic Aspergillus fumigatus Isolated from Decomposting Orange Peels. Brazilian Journal of Microbiology. 36: 63-69. http://dx.doi.org/10.1590/S1517-83822005000100013.

[32] Dinu, D., Nechifor, M. T., Stoian, G., Costache, M., Dinischiotu, A. 2007. Enzymes with New Biochemical 
Properties in the Pectinolytic Complex Produced by Aspergillus niger MIUG 16. Journal Biotechnology. 131: 128137. DOI: 10.1016/j.jbiotec.2007.06.005.

[33] Demir Handee. 2012. Production of Pectinase from Aspergillus Sojae by Solid-state Fermentation. Doctor of Philosophy. Izmir Institute of Technology.

[34] Gogus Nihan. 2006. Effect of The Morphology of Aspergillus Sojae on Pectinase Enzyme and the Optimization of Fermentation Conditions. Degree of Master of Science in Food Engineering. Thesis. Izmir Institute of Technology.

[35] Jayani, R. S., Saxena, S. and Gupta, R. 2005. Microbial Pectinolytic Enzymes: A Review. Process Biochemistry. 40: 2931-2944. https://doi.org/10.1016/j.procbio.2005.03.026.

[36] Kashyap, D. R., Vohra, P. K., Chopra, S., Tewari, R. 2001. Applications of Pectinase in the Commercial Sector: A Review. Bioresource Technology. 77: 215-227. https://doi.org/10.1016/S0960-8524(00)00118-8.

[37] Alcantara, S. R., Leite, N. J. and Da Silva, F. L. H. 2013. Scale Up of Polygalacturonase Production by Solid State Fermentation Process. InTech. 399-420. DOI: $10.5772 / 53152$.

[38] Shuler M. L., Kargi, F. 2002. Bioprocess Engineering Basic Concepts. 2nd ed. Prentice-Hall, Inc., USA.

[39] Eisenmenger, M. J. and Reyes-De-Corcuera, J. I. 2009. High Pressure Enhancement of Enzymes: A Review. Enzyme and Microorganism. https://doi.org/10.1016/j.enzmictec.2009.08.001.

[40] Adiele, Nora, I. 2012. Production and Characterization of Pectinase Induced from Aspergillus niger using Pectin Extracted from Pineapple Peels as Carbon Source. Master of Science. University of Nigeria Nsukka. Microbial Technology. 45: 331-347.

[41] Nirmaladevi, D., Anilkumar, M. and C. Sriniva, C. S. 2014. Production and Characterization of Exopolygalacturonase from Fusarium oxysporum f. sp. lycopersici. International Journal of Pharma and Bio Sciences. 5(1): 666-675.

[42] Thakur, A., Pahwa, R., Singh, S. and Gupta, R. 2010. Production, Purification, and Characterization of Polygalacturonase from Mucor circinelloides ITCC 6025 Enzyme Research. 1-7. http://dx.doi.org/10.4061/2010/170549.

[43] Moyoa, S., Gashea, B. A., E. K. Collisona, E. K. and Mpuchane, S. 2003. Optimising Growth Conditions for the Pectinolytic Activity of Kluyveromyces wickerhamii by using Response Surface Methodology. International Journal of Food Microbiology, 85: 87-100. https://doi.org/10.1016/S0168-1605(02)00503-2.

[44] Soroor, M. A. M., -El-Hady, A. M. G., El-Sayed, M. S. Mahdy, El-Badery, M. O., Shousha, W. G. and El-Khonezy, M. I. 2013. Purification and Characterization of Polygalacturonases Produced by Trichoderma reesei F418 using Lemon Peels and Rice Straw under Solid-State Fermentation. Journal of Applied Sciences Research. 9(4): 3184-3198.
[45] Buga, M. L., Ibrahim, S. and Nok, A. J. 2010. Partially Purified Polygalacturonase from Aspergillus niger (SA6). African Journal of Biotechnology. 9(52): 8944-8954.

[46] Patil, N. P. and Chaudhari, B. L. 2010. Production and Purification of Pectinase by Soil Isolate penicillium sp and Search for better Agro-Residue for Its SSF. Recent Research in Science and Technology. 2(7): 36-42.

[47] Hamdy Hossam, S. 2005. Purification and Characterization of the Pectin Lyase Produced by Rhyzopus oryzaeGrown on Orange Peels. Annals of Microbiology. 55(3): 205-21 1 .

[48] Rasheedha, A B., Kalpana, M. D., Gnanaprabhal, G. R., Pradeep, B. V and Palaniswamy, M. 2010. Production and Characterization of Pectinase Enzyme from Penicillium chrysogenum. Indian Journal of Science and Technology. 3(4): 377-381.

[49] Arijit, D., Sourav, B., Naimisha, R. V. and Sundara Rajan, S. S. 2013. Improved Production and Purification of Pectinase from Streptomyces sp. GHBA10 Isolated from Valapattanam Mangrove Habitat, Kerala, India. International Research Journal of Biological Sciences. 2(3): 16-22.

[50] Biscaro, D. P., and Cano, E. C. 2014. Purification and Characterization of a Unique Pectin Lyase from Aspergillus giganteus able to Release Unsaturated Monogalacturonate during Pectin Degradation. Enzyme Research. 1-8. http://dx.doi.org/10.1155/2014/353915.

[51] Yuan, P., Meng, K., Wang, Y., Luo, H., Shi, P., Huang, H., Bai, Y., Yang, P. and Yao, B. 2014. A Protease-resistant Exopolygalacturonase from Klebsiella sp. Y1 with Good Activity and Stability over a Wide Ph Range in the Digestive Tract. Bioresource Technology. 123: 171-176. DOI: 10.1016/j.biortech.2012.07.037.

[52] Prasad, Y. P., Lin, C., Shen, Z. and Qin, W. 2015. Characterization of Pectin Depolymerising Exo Polygalacturonase by Bacillus sp. HD2 Isolated from the Gut of Apis mellifera L. Microbiology Discovery. 3(2): 1-8. DOI: http://dx.doi.org/10.7243/2052-6180-3-2.

[53] Mohsen, S. M., Bazaraa, W. A. and Doukani, K. 2009. Purification and Characterization of Aspergillus niger U-86 Polygalacturonase and Its use in Clarification of Pomegranate and Grape Juices. $4^{\text {th }}$ Conference on Recent Technologies in Agriculture. 805-817.

[54] Singh S. A. and Rao A. G. A. 2002. A Simple Fractionation Protocol for, and a Comprehensive Study of the Molecular Properties of Two Major Endopolygalacturonases from Aspergillus niger. Biotechnol. Appl. Biochem. 35: 115-123. https://doi.org/10.1042/BA20010077.

[55] Semenova, M. V., Grishutin, S. G., Gusakov, A. V., Okunev, O. N. and Sinitsyn, A. P. 2003. Isolation and Properties of Pectinases from the Fungus Aspergillus japonicus. Biochemistry. 68(5): 559-569. https://doi.org/10.1023/A:1023959727067.

[56] Gummadi, S. N., Manoj, N. and Kumar, D. S. 2007. Structural and biochemical properties of pectinases. In. Polania, J. and MacCabe, A. P. (Eds.). Industrial Enzymes. Springer. 99-115. https://doi.org/10.1007/1-4020-5377-0_7. 